\title{
A IMPORTÂNCIA DA DEFINIÇÃO DE TERMOS E CONCEITOS NA SUSTENTABILIDADE DA "TEORIA" DA RESTAURAÇÃO DE CESARE BRANDI
}

Denise Puertas de Araújo ${ }^{1}$

\section{Resumo}

A definição de uma terminologia científica, especificando termos e conceitos, é mais do que ponto de partida - algo essencial para a sustentabilidade e verificabilidade de qualquer teoria. Dentro desse quadro, a "Teoria" da Restauração, de Cesare Brandi, constitui valiosíssima contribuição pois, tornando-a sustentável a partir da sólida definição de conceitos, seu autor procura livrar do arbítrio a restauração dos bens culturais.

Palavras-chave: preservação, restauração, bens culturais, metodologia.

\section{Resumen}

La definición de una terminología científica, especificando términos y conceptos es, más que un punto de partida, el paso esencial para la sustentabilidad y la verificación de cualquier teoría. Dentro de ese cuadro, la "Teoría" de Restauración de Cesare Brandi, constituye una valiosa contribución pués, tornandola sustentable a apartir de la sólida definición de conceptos, su autor busca extraer del arbitrio la restauración de los bienes culturales.

Palabras Claves: preservación, restauración, bienes culturales, metodología.

A definição de uma terminologia científica, especificando termos e conceitos, é mais do que ponto de partida - algo essencial para a sustentabilidade e verificabilidade de qualquer teoria. Para FERRARI (1982, p. 94) "a conceituação consiste em eliminar os termos retóricos ao mesmo tempo que se explicita a estrutura lógica". Dentro desse quadro, a "Teoria" da Restauração, de Cesare Brandi", constitui valiosíssima contribuição pois, tornando-a sustentável a partir da sólida definição de conceitos, seu autor procura livrar do arbítrio a restauração dos bens culturais.

Desde que se passou a perceber a importância do patrimônio cultural ${ }^{4}$, diversas formas de intervir sobre o mesmo foram preconizadas. A partir do século XIX, o conceito de restauração surge com uma carga cultural, diferentemente do que acontecia até então, quando outros valores (uso, estudos etc) constituíam a principal justificativa para existência desta. Dentro desse contexto, Eugène Emmanuel Viollet-le-Duc dava a seguinte definição: "Restaurar um edifício não é mantê-lo, repará-lo ou refarêe-lo, é restabelecê-lo num estado completo que pode não ter existido nunca em um dado momento". (VIOLLET-LE-DUC: 2000, p.29). Embora Viollet-le-Duc tentasse passar alguma diretriz, a metodologia para a ação era inexistente, ficando a cargo de cada arquiteto, ao fazer a intervenção, colocar-se no papel do autor da

\footnotetext{
${ }^{1}$ Mestranda em História e Fundamentos da Arquitetura e Urbanismo pela FAUUSP.

2 Neste trabalho, usarei a palavra "teoria" entre aspas em virtude da mesma não se apresentar no sentido usual e próprio do termo, ou seja, como um conjunto de hipóteses elaboradas através da observação do real. Ainda que a obra de Brandi seja composta por pequenas - porém não menos importantes - teorias, ela é, antes de tudo, uma metodologia para as ações de restauro. Não usarei este último termo, em substituição, em respeito ao título original da obra.

3 (1906-1988). Cesare Brandi era formado em direito e letras, mas dedicou sua obra à crítica e também à história da arte, tendo feito alguns trabalhos com Giulio Carlo Argan. Fundou, em 1939, o Instituto Centrale del Restauro, em Roma, tendo sido seu diretor até 1959.

${ }^{4}$ Os exemplos tratados aqui recairão, principalmente, sobre o patrimônio cultural arquitetônico.
} 
obra. Tal intervenção tinha por finalidade reconstruir um edifício da forma que, como se imaginava, ele teve um dia (no caso de encontrar-se destruído ou mutilado) ou poderia ter tido (caso em que as obras, por qualquer motivo, tivessem sido paralisadas e o edifício não tivesse sido finalizado). Fica claro o campo profícuo para o arbítrio, posto que, à exceção da principal premissa, que era a de usar o estilo original, os arquitetos contemporâneos, transpostos para uma dada época, tinham grande liberdade de ação dentro de um campo isento de critérios. Outras questões também acabavam ferindo esse ato de transmissão para o futuro uma vez que o que seria legado poderia constituir um falso. Na tese "Um Estado completo que pode jamais ter existido" Antonio Luiz Dias de ANDRADE (1993) relata o caso da restauração da torre da igreja de Nossa Senhora do Rosário, em Embu: ao retomar o 'espírito da época', os restauradores acabaram por conferir um aspecto que não era nem o original, nem o de uma intervenção contemporânea uma vez que, ao ser descoberta uma foto onde a igreja aparecia ao fundo, verificou-se que a solução adotada no restauro não havia sido a mesma utilizada pelos construtores do templo.

Esse e outros erros foram constantes; mesmo em casos onde havia a boa intenção, a falta de métodos e critérios foram cruciais na definição de resultados pouco satisfatórios.

E é contra essa falta de método, contra esse campo vago onde a restauração se inseria, que Cesare Brandi propõe uma metodologia para a prática da restauração. Esta última, com a carga cultural que a aproximava de um legado, uma herança quase que genética, constitui, segundo ele "o momento metodologico do reconhecimento da obra de arte, na sua consistência física e na sua dúplice polaridade estética e histórica, com vistas à sua transmissão para o futuro" (BRANDI: 2004 p. 30).

Ao definir conceitos relativos à obra de arte como matéria, unidade potencial e tempo, Brandi dá sustentabilidade e credibilidade à sua proposta e antecipa questões que vêm à mente de todos aqueles que estudam o assunto, presenteando-os com uma metodologia de restauração muito bem estruturada. Além disso, como Ciência que se pretendia, seus estudos deveriam ser aplicáveis a todos os campos onde a restauração se fizesse necessária (pintura, arquitetura, escultura etc), diferentemente de outras propostas, como a de Camillo Boito ${ }^{5}$, que particularizava a restauração, valendo critérios diferentes para categorias diferentes de bens a serem restaurados. Para ele, por exemplo, as adições que as esculturas sofreram ao longo do tempo deveriam ser descartadas ao passo que, para a arquitetura, deveriam ser levadas em conta, ficando evidente, para essa manifestação artística, o respeito que os acréscimos ao longo da história deveriam ter.

É interessante analisar alguns dos conceitos acima citados, a fim de entender como suas precisas definições contribuíram efetivamente para a sustentação da proposta brandiana.

O primeiro deles, na seqüência em que aparece no texto, trata da matéria da obra de arte, que representa o "tempo e o lugar da intervenção de restauro" (BRANDI: 2004, p. 36) sendo dividida em aspecto e estrutura. O conflito entre essas duas instâncias da matéria é resolvido com a prevalência, quando não é possível uma conciliação harmônica, do aspecto sobre a estrutura, posto que é o primeiro que diretamente confere ao bem o caráter de arte. Brandi coloca como motivo de muitos erros que aconteceram em restaurações existentes o fato de nunca ter sido levada em conta essa distinção que a matéria da obra de arte encerra em si mesma. E como exemplo, cita o ato de considerar idênticos o mármore bruto de uma pedreira e aquele que, modificado, transformou-se numa estátua. Assim, enquanto o mármore bruto tem apenas sua constituição física, o mármore da escultura passou, a partir

\footnotetext{
${ }^{5}$ Camillo Boito apresenta suas idéias numa Conferência feita na Exposição de Turim, em 1844.
} 
do trabalho de um artista, a ser veículo de uma imagem, tendo também se historicizado e, nesse momento, como imagem, segundo a definição de Brandi, desdobra-se em aspecto e estrutura. Dessa forma, aqueles que acreditam que basta encontrar a jazida de onde seja extraído material idêntico ao da obra que se deseja restaurar para que tal restauração seja correta e não contraditória com o próprio conceito de restauração, caem no erro de achar que a matéria é a mesma, quando, de fato, não é. Sendo refeita em outra época, por outras mãos, pertencerá à atualidade em que é inserida no monumento e, ao se pretender igual, constituirá um falso histórico e também artístico.

Outro conceito, talvez o mais importante, inclusive, é o de Unidade Potencial da Obra de Arte. Para Brandi, cada pedaço de uma obra faz parte de um inteiro e não de um total. Assim, cada fragmento separado perde a concatenação formal imposta pelo artista, tornando-se inerte. A obra de arte, ainda que fracionada, não pode ser considerada como sendo composta por partes (o que faria dela um total). No entanto, cada fragmento de uma obra dilacerada, por sua vez, ainda que não seja uma obra de arte distinta, tem um potencial de voltar a ser, ou seja, de atingir novamente a unidade perdida. Esse fragmento, como uma peça de quebra-cabeças que tem certo número de encaixes, apresenta também um potencial limitado a partir do qual, rompido esse limite, não pode mais restabelecer a unidade perdida. Respeitado esse limite, o que se almeja é que "... em casos em que, na sua matéria, a obra de arte estiver dividida, será necessário buscar desenvolver a unidade potencial originária que cada um dos fragmentos contém, proporcionalmente à permanência formal ainda remanescentes neles" (idem, p. 46). Como método a ser seguido para restabelecer a unidade, há uma série de instruções, e também, como alerta, casos que não foram considerados satisfatórios quando testados pelo Instituto Central de Restauração, (ICR) em Roma, como o da tinta neutra, a fim de que, mais uma vez, o produto a ser transmitido não fosse um falso ao mesmo tempo em que também não tivesse comprometido suas qualidades estéticas.

Por fim, ao definir o tempo em relação à obra de arte, Brandi indica qual é o exato instante onde deve ser inserido o restauro. Para ele, a obra de arte apresenta três momentos distintos: o primeiro é o de duração, constituído pelo intervalo que vai da concepção à exteriorização, pelo artista, de sua obra de arte. O segundo representa o intervalo que vai do fim do processo criativo ao momento em que a consciência de cada um atualiza a obra de arte e o terceiro e último é um átimo desse clarão da obra de arte na consciência. A grande questão, para Brandi, ao definir esses tempos, é estabelecer em qual deles é lícita e honesta a ação do restauro. Esta, quando dada no primeiro tempo, "se poderá parecer que seja um restauro, dado que a operação acontece sobre uma imagem por sua vez concluida, na realidade, tratarse-á de uma refusão da imagem em outra imagem, de um ato sintético e criativo que desautoriza a primeira imagem e a sela em uma nova". (idem, p. 60). Assim, os exemplos de restauração seguidos conforme indicava Viollet-le-Duc inserem-se nesse tempo, fundindo uma nova imagem àquela primitiva. A repristinação, tipo de intervenção que procura conferir ao monumento seu estado primitivo, é uma ação que se insere no segundo tempo da obra de arte, entre sua conclusão e o presente, eliminando este mesmo intervalo e negando a história pela qual passou a construção. Este é o caso da Vila Savoye, de Le Corbusier, onde as ações tomadas sempre tentam retorná-la ao exato momento do fim de sua construção, causando a impressão de que o tempo nunca agiu sobre a obra, que se mostra sempre acabada e nova. Assim, o único momento legítimo para a restauração é aquele do presente da consciência observadora, onde "a obra de arte está no átimo e é presente histórico, mas é também passado e, a custo de outro modo, de não pertencer à consciência bumana, está na bistória" (idem, p. 61). O próprio 
restauro, portanto, deve ser evento histórico, pontuado e datado, uma vez que ele mesmo se insere no processo de transmissão da obra de arte.

Esses conceitos definidos acabam por apontar para alternativas específicas no processo de restauração, ao mesmo tempo em que, embasando as propostas de Cesare Brandi, sustentam-nas e sistematizam as ações, conferindo-lhes métodos. Em muitos casos, implícito em cada conceito, já vem a reprovação para alguns atos que eram - e ainda são recorrentes nas práticas de restauro e que, muito provavelmente, foram disseminados antes de serem feitos sobre eles uma análise mais profunda de todos os elementos envolvidos (tempo, matéria etc). Dessa forma, ao definir a 'unidade potencial da obra de arte', Brandi já aponta o caminho (posteriormente detalhado) de como lidar com as ruínas, por exemplo. Com o mesmo conceito, vem a idéia de não separação das partes de uma obra (como retirar uma coluna de uma edificação e isolá-la num museu, selecionando apenas alguns elementos para a conservação. Com essa definição, a ambiência também é levada em conta). Ou seja, aceitando-se os conceitos, algumas práticas tornam-se evidentemente agressivas e contraditórias da própria "Teoria", portanto, ilegítimas e refutadas. Passa-se também a definir os limites do que é e do que não é restauração. Nesse contexto, a sua obra se mostra como uma grande evolução, com bases mais sólidas que, embora anteriormente e por outros intencionadas, nunca haviam de fato sido alcançadas. Com seus métodos, mostra que o objeto da transmissão deve chegar verdadeiro ao receptor; que o tempo, fundamental na constituição física da matéria e da imagem, deve ser respeitado; que a ação do interventor é ato crítico e, ao não negar a história, insere-se nela. Evidentemente, seus conceitos são - e devem - ser objetos de futuras revisões, posto que o conhecimento científico é cumulativo ao mesmo tempo em que é evolutivo, mas o principal é que abriram caminhos, metodologicamente embasados, para os fins que consideram adequados.

\section{Bibliografia:}

ANDRADE, Antonio Luiz Dias de. Um estado completo que pode jamais ter existido. São Paulo: Faculdade de Arquitetura e Urbanismo. Tese de Doutoramento, 1993.

BRANDI, Cesare. Teoria da Restauração. Cotia: Ateliê Editorial, 2004. Tradução: Beatriz Mugayar Kühl. Apresentação: Giovanni Carbonara.

FERRARI, Alfonso Trujillo. Metodologia da Pesquisa Científica. São Paulo: McGrawHill do Brasil, 1982.

LAZARSFELD, P. De los conceptos a los índices empíricos in BOUDON, Raymond e LAZARSFELD, Paul. Metodología de las ciencias sociales - 1. Conceptos y índices. Barcelona: Editora Laia, 1985. pp 35-46.

RUSKIN, John. Siete lámparas de la arquitectura. Buenos Aires: Ateneo, 1956.

VIOLLET-LE-DUC, Eugène Emmanuel. Restauração. São Paulo: Ateliê Editorial, 2000. Tradução: Beatriz Mugayar Kühl. Apresentação: Giovanni Carbonara. 